\title{
Research on the Structure of Fish Collagen Nanofibers Influenced Cell Growth
}

\author{
Gang Zhou, ${ }^{1,2}$ Guimin Zhang, ${ }^{3}$ Zhe Wu, ${ }^{1}$ Yongzhao Hou, ${ }^{1}$ Ming Yan, ${ }^{1}$ Haifeng Liu, ${ }^{1,2}$ \\ Xufeng Niu, ${ }^{1,2}$ A. Ruhan, ${ }^{1}$ and Yubo Fan ${ }^{1,2}$ \\ ${ }^{1}$ Key Laboratory for Biomechanics and Mechanobiology of Ministry of Education, School of Biological Science and Medical Engineering, \\ Beihang University, Beijing 100191, China \\ ${ }^{2}$ Research Institute of Beihang University in Shenzhen, Shenzhen 518057, China \\ ${ }^{3}$ The First Affiliated Hospital of Kunming Medical University, Kunming 650032, China \\ Correspondence should be addressed to Yubo Fan; yvbofan@buaa.edu.cn
}

Received 6 June 2013; Accepted 24 June 2013

Academic Editor: Xiaoming Li

Copyright (C) 2013 Gang Zhou et al. This is an open access article distributed under the Creative Commons Attribution License, which permits unrestricted use, distribution, and reproduction in any medium, provided the original work is properly cited.

Electrospinning is highlighted in biomaterials field. The structures of nanofibers depend on various parameters, which are related closely to the bioactivity of biomaterials. The aim of this research is to analyze the structure of fish collagen nanofibers and to propose the new criterion for cell growth. This paper focused on the flow rate of solvent during the electrospinning. Through the cell culture, the relationship of the structure and cell growth is investigated. The results obtained in this study provide an understanding of the behaviors of cell growth under different structure of fish collagen nanofibers scaffold.

\section{Introduction}

Recently, electrospinning is gaining tremendous interest in the tissue engineering $[1,2]$. Electrospinning has been explored as a processing strategy for the production of physiologically relevant tissue engineering scaffolds. This adaptable technology can selectively process a variety of polymers $[3,4]$ into nanosize to micron scale diameter fibers. These nanofibers can mimic the dimensions, structure, and function of native extracellular matrix (ECM) constituents [5]. Moreover, the electrospun nanofibers have large surface area to volume ratio, which attached ligands [6], growth factors [7], and other biomolecules [8] onto fiber surfaces. Then, these factors locally modulate cell and tissue function and lastly enhance tissue regeneration $[9,10]$.

For tissue engineering applications, collagen-based compounds are very suitable, because they possess some intrinsic favorable biological properties, like superior biocompatibility and bioactivity [11]. Collagen molecules have a triple-helical structure and the presence of 4-hydroxyproline resulting from a posttranslational modification of peptide-bound prolyl residues provides a distinctive marker of these molecules
[12]. Until now, 28 collagen types have been identified; I, II, III, and V are the main types that make up the essential part of collagen in bone, cartilage, tendon, skin, and muscle. They also exist in fibrillar forms with elaborate 3D arrays in ECM [13]. From the biomimetic point of view, collagen has been electrospun into nanofibrous scaffolds for tissue engineering $[14,15]$. However, the main sources of collagen are usually from terrestrial animals, such as porcine and bovine donors. There are some zoonosis outbreaks [16-18], such as transmissible spongi form encephalopathy (TSE), bovine spongiform encephalopathy (BSE), and foot and mouth disease (FMD) in pigs and cattle. Thus, collagen derived from these sources has limited. Therefore, safer sources of collagen should be utilized for the biomaterials field. Compared with terrestrial animals, hydrocele animals are good alternative resources for collagen. Fish scale is composed of almost $50 \%$ collagen, mostly type I. It was highlighted due to its low antigenicity and excellent biocompatibility [19]. Consequently, in this study a novel fish collagen was investigated that finally can be used as an electrospun material.

The electrospun parameters not only affected the average diameter of nanofibers, but also the structure of scaffolds. 


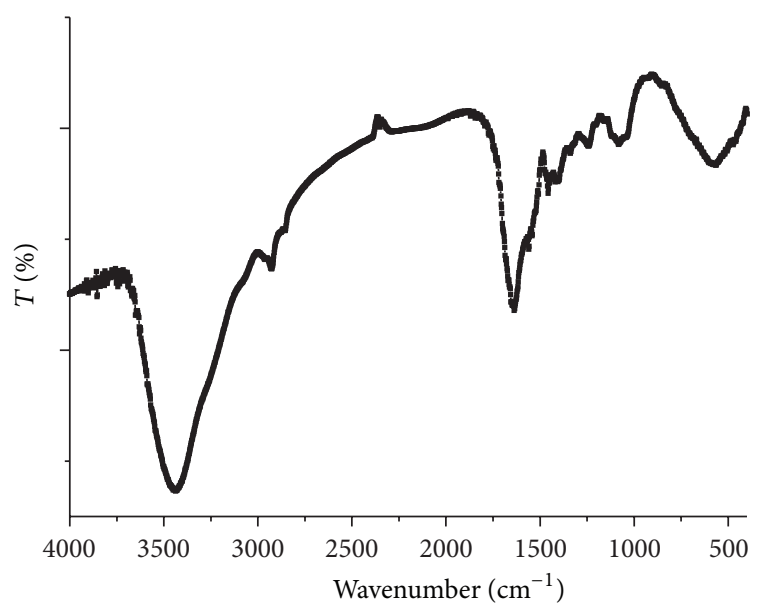

FIGURE 1: FT-IR spectrum of fish collagen.

Few papers researched on the cell growth under the different structure of nanofibers in scaffolds. In the present study, the electrospinning method was used to prepare fish collagen nanofibers. The properties of these nanofibers were characterized and analyzed by Fourier transform-infrared (FT-IR) and scanning electron microscope (SEM). Moreover, cell culture experiment was done to investigate the relationship between cell and different structure of this material.

\section{Materials and Methods}

2.1. Materials. Tilapia mossambica was bought from supermarket. It is healthy.

2.2. Preparation of the Fish Collagen. The fish scales were scraped from Tilapia mossambica. They were trimmed of fur and excess fat. Then, strips of scales were washed and cleaned by distilled water repeatedly 5 times, drying at $25^{\circ} \mathrm{C}$.

The dry scales placed in distill water and treated for $1 \mathrm{~min}$ in a commercial flash extractor (Model JHBE-50T, Henan Jinnai Sci-Tech Development Co., China). The production was dissolved in $0.5 \mathrm{M}$ acetic acid, stewing in room temperature for $4 \mathrm{~h}$, and then centrifuged at $5000 \mathrm{r} / \mathrm{min}$ for 15 minutes. The liquid supernatant was harvested filtering; solid $\mathrm{NaCl}$ was added to the liquid supernatant to a final concentration of $0.9 \mathrm{M}$, incubated at $4^{\circ} \mathrm{C}$ for $12 \mathrm{~h}$. Then, the solution was centrifugation at $5000 \mathrm{r} / \mathrm{min}$ for $20 \mathrm{~min}$ to remove all nonsoluble collagen fragments. Materials were separated by adding $\mathrm{NaCl}$ to a concentration of $0.9 \mathrm{M}$ to induce precipitation. The precipitated collagen was collected by centrifugation at $5000 \mathrm{~g}$ for $20 \mathrm{~min}$, redissolved in distill water, and dialyzed for 4 days. The final collagen solution was freeze-dried and stored at $-20^{\circ} \mathrm{C}$ until further use.

2.3. Electrospinning of Fish Collagen. Fish collagen was dissolved in hexafluoro-2-propanol (HFIP; Fluka Chemie $\mathrm{GmbH}$, Germany) to generate a $10 \%(\mathrm{wt} / \mathrm{v})$ solution. Electrospinning was performed with a steel capillary tube with a $2 \mathrm{~mm}$ inside diameter tip mounted on an adjustable, electrically insulated stand. The capillary tube was maintained at a high electric potential for electrospinning and was mounted in the parallel plate geometry. The capillary tube was connected to a syringe filled with the fish collagen/HFIP solution.

During this step, the ambient temperature was $25 \pm 1^{\circ} \mathrm{C}$, the humidity was $58 \pm 2 \%$. The distance between collection plate and needle tip was $15 \mathrm{~cm}$. The applied voltage was $15 \mathrm{kV}$. Nanofibers were electrospun on the gap collector by adjusting the flow rate of fish collagen solution at different variants using a syringe pump. The flow rate of collagen solvent was $0.1 \mathrm{~m} / \mathrm{s}$ (indicate I); $0.5 \mathrm{~m} / \mathrm{s}$ (II); $1.0 \mathrm{~m} / \mathrm{s}$ (III); $1.5 \mathrm{~m} / \mathrm{s}$ (IV), respectively.

\subsection{Characterization of Materials}

2.4.1. FT-IR Analysis. FT-IR spectroscopic analysis of fish collagen was performed using a Thermo Nicolet 170SX FT-IR Spectrometer in the region from 400 to $4000 \mathrm{~cm}^{-1}$ (spectral resolution $4 \mathrm{~cm}^{-1}, 32$ scans per spectrum).

2.4.2. SEM Observation. The surface morphology of fish collagen scaffold was viewed under a scanning electron microscope (Hitachi S-450), with an accelerated voltage of $10 \mathrm{kV}$. All samples were coated with a sputter coater (BALTEC Inc.) equipped with a gold target to increase electrical conductivity. The average diameter and diameter distribution of fish collagen nanofibers were measured from SEM images by ImageJ program, with an accuracy of $\pm 0.01 \mathrm{~nm}$. All the samples have been measured using the 5 different SEM images.

2.4.3. Cell Culture. HEK-293 cells were cultured and maintained in logarithmic growth phase in DMEM (Gibco, USA) medium containing $10 \%$ fetal bovine serum (FBS) and $1 \%$ penicillin/streptomycin at $37^{\circ} \mathrm{C}$ and $5 \% \mathrm{CO}_{2}$. Cell viability was measured using the 3-(4,5-dimethyl-2-thiazolyl)-2, 5diphenyl-[2H]-tetrazolium bromide (MTT) assay. The dye MTT is taken and metabolized to purple by viable mitochondria. Cells were counted and plated in 96-well plates at a rate of $1 \times 10^{4}$ cells per well and incubated in $200 \mu \mathrm{L}$ cell culture medium. Prior to dilution with culture medium, the fish collagen was sterilized by UV light for $12 \mathrm{~h}$. After incubation for $1,3,5$, and 7 days, $20 \mu \mathrm{L}$ MTT solution $(5 \mathrm{mg} / \mathrm{mL}$, prepared with PBS, pH 7.4) was added to each well and incubated at $37^{\circ} \mathrm{C}$ and $5 \% \mathrm{CO}_{2}$ for an additional $4 \mathrm{~h}$. The purple MTT was dissolved in $150 \mu \mathrm{L}$ dimethyl sulfoxide solution (DMSO) (Sigma, USA). The activity of the mitochondria, reflecting cellular viability, was evaluated by measuring the optical density at $490 \mathrm{~nm}$ using an ELISA microplate reader (Bio-Rad Instruments, Inc.). The cell viability (\%) of the treated cells was calculated in relation to the negative controls (100\%).

2.5. Statistical Analysis. Data are given as means \pm S.E.M. For statistical comparison, $t$-test or one-way ANOVA followed by Tukey's test was employed. ${ }^{*} P<0.05,{ }^{* *} P<0.01$, and ${ }^{* * *} P<$ 0.001 were considered to be statistically significant. 


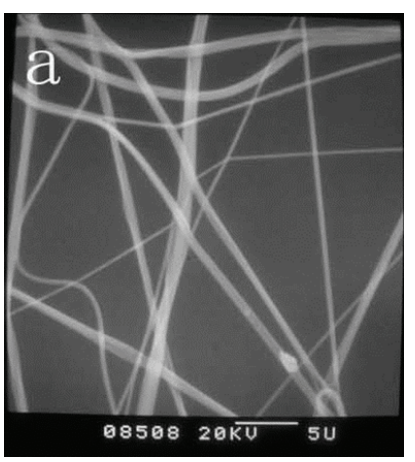

(a)

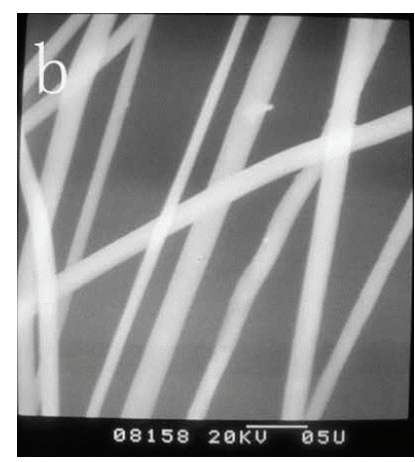

(b)

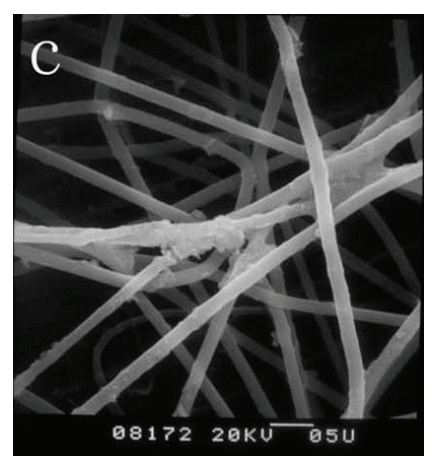

(c)

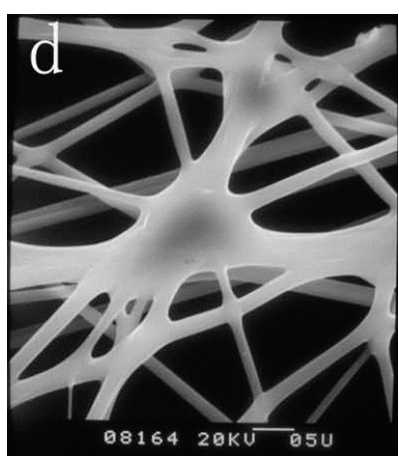

(d)

FIGURE 2: SEM images of electrospun fish collagen when the flow rate of solvent was (a) $v=0.1 \mathrm{~mL} / \mathrm{h}$ (indicate I); (b) $v=0.5 \mathrm{~mL} / \mathrm{h}$ (II); (c) $v=1.0 \mathrm{~mL} / \mathrm{h}(\mathrm{III}) ;(\mathrm{d}) v=1.5 \mathrm{~mL} / \mathrm{h}(\mathrm{IV})$.

\section{Result and Discussion}

3.1. FT-IR Analysis. The FT-IR spectrum of collagen depicts characteristic absorption bands at 1634, 1544, and $1250 \mathrm{~cm}^{-1}$, which represent the amide I, II, and III bands of collagen [20]. The main amide III characteristic absorption band is observed at $1250 \mathrm{~cm}^{-1}$, with another peak seen at $1335 \mathrm{~cm}^{-1}$, as shown in Figure 1. The result of FT-IR measurement indicates the isolation of fish collagen that can be accounted for Type I collagen.

3.2. SEM Observation. Nanofibers were manufactured from fish collagen solution of $4 \%(\mathrm{w} / \mathrm{v})$ concentration. The first series of experiments were carried out at the flow rate of solvent $0.1 \mathrm{~mL} / \mathrm{h}$, the second $0.5 \mathrm{~mL} / \mathrm{h}$, the third $1.5 \mathrm{~mL} / \mathrm{h}$, and the fourth $1.5 \mathrm{~mL} / \mathrm{h}$. The morphologies of scaffold were presented in Figure 2. Each variant produced different morphologies of fibers (shown in Figure 2). With the flow rate increase, system produced a population that was skewed towards the production of larger diameters during the electrospinning.

During the observation, the four SEM images for each variant of flow rate were detected, respectively. The $146 \pm$ 57 diameters of fish collagen nanofibers for the I variant, $121 \pm 17$ diameters of nanofibers for II variant, $283 \pm 12$ diameters of nanofibers for III variant, and $318 \pm 30$ nanofibers for IV variant were found and measured. The structure of fish collagen scaffold also depends on the flow rate. The electrospun fish collagen nanofibers were parallel aligned without defects at II variant $(0.5 \mathrm{~mL} / \mathrm{h})$. At the $0.1 \mathrm{~mL} / \mathrm{h}$, the nanofibers were randness. At the flow rate of $1.0 \mathrm{~mL} / \mathrm{h}$, the surface of nanofiber was rather roughness (shown in Figure 2(c)). It resulted from some nanofibers get together. At the highest flow rate $(1.5 \mathrm{~mL} / \mathrm{h})$ of solvent, small diameter fibers interspersed with beads and stuck together, composing the larger diameter fibers and highly aligned. This change would decrease the porosity of scaffold.

In the next step of investigations, the dispersions of fish collagen nanofibers have been studied. The frequency distributions of all series were discussed in Figure 3. Four histograms demonstrated that the diameter of nanofibers in all cases was distributed in different distributions. In Figure 3(a), three peaks were remarked observed: the first peak was around $50 \mathrm{~nm}$, the second peak was around $100 \mathrm{~nm}$, while the third was $150 \mathrm{~nm}$. A similar result, the distribution with several peaks, could be detected in Figure 3(b): the first peak is around $75 \mathrm{~nm}$, the second is around $100 \mathrm{~nm}$, and the third is $125 \mathrm{~nm}$. With the flow rate increase, the histogram really has one main peak around $300 \mathrm{~nm}$. These changes were the sticking of fish collagen nanofibers. During the electrospinning process, the nanofibers were manufactured by means of electrostatic forces between two electrodes [21]. The diameters of nanofibers usually changed and they depend on various parameters. The different diameters of fibers influenced the structure of scaffold and herewith the enduse properties of such kind of nanomaterial. Therefore, the flow rate of solvent was a very important parameter for the structure of nanofibers. Using the higher flow rate, more stuck fiber scaffolds were forming.

3.3. MTT Evaluation. Cell proliferation on the collagen was studied in vitro by MTT test. Because of the differences in the chemical composition, conformation, porosity, and hydrophobicity of matrix affect cellular activities [22, 23], time-dependent changes were observed in the cellular behavior in response to collagen compositions. In 7-day cell cultures, the cell number increased with culture time on all tested groups (Figure 4). While at day 1 there was no statistically significant difference among the collagen and the control groups, at the later time point (5th day for HEK-293 cells), the cell numbers on collagen were significantly higher than those cocultured with control, which implied that the fish collagen favored cell attachment. Fish collagen nanofiber scaffolds exhibited excellent support for cell attachment and differentiation. In addition, there was a trend showing the highest number of cells in II variant group compared to others. Electrospun scaffolds of collagen composed of small diameter fibers induced the expression of a highly flattened and stellate cell shape at this flow rate. Critical to the bioengineering paradigm is the development of tissue engineering scaffolds that can support the proliferation and penetration [24]. While at the highest flow rate of solvent cell 


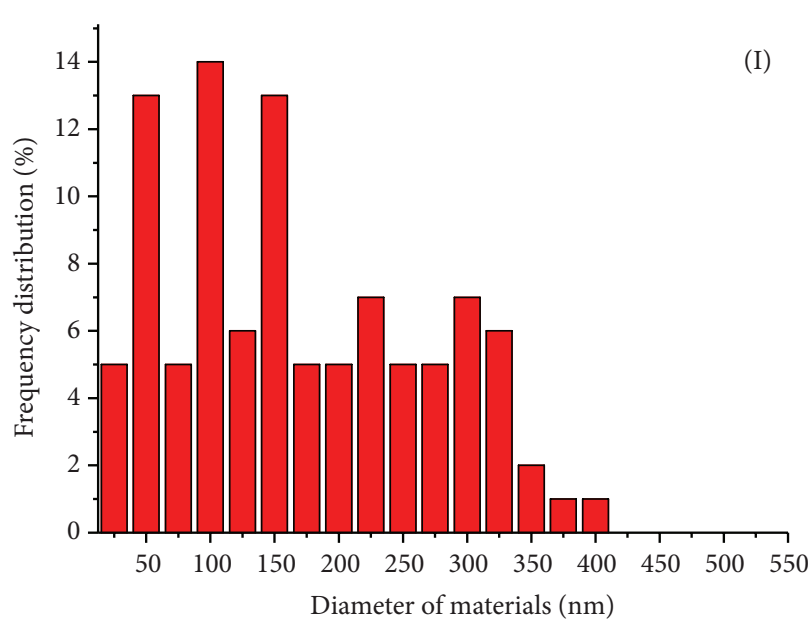

(a)

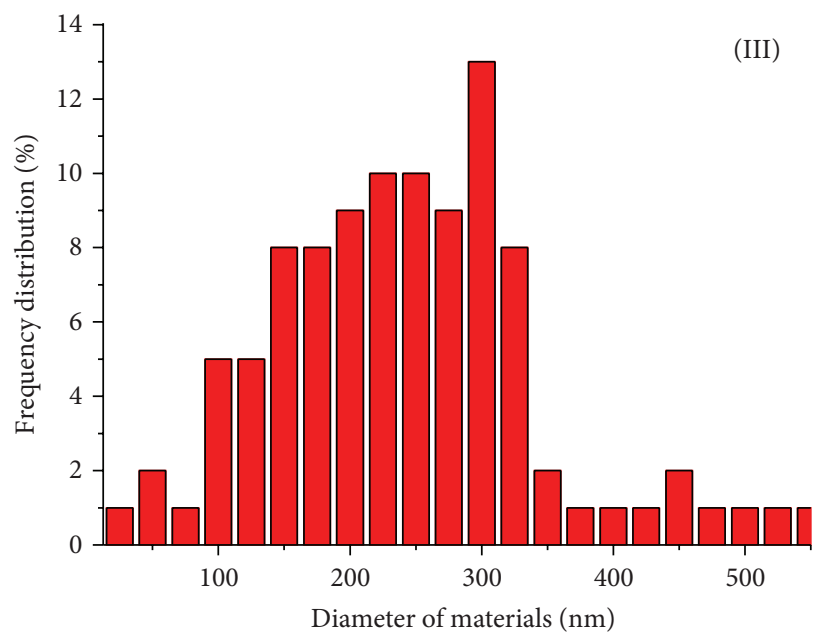

(c)

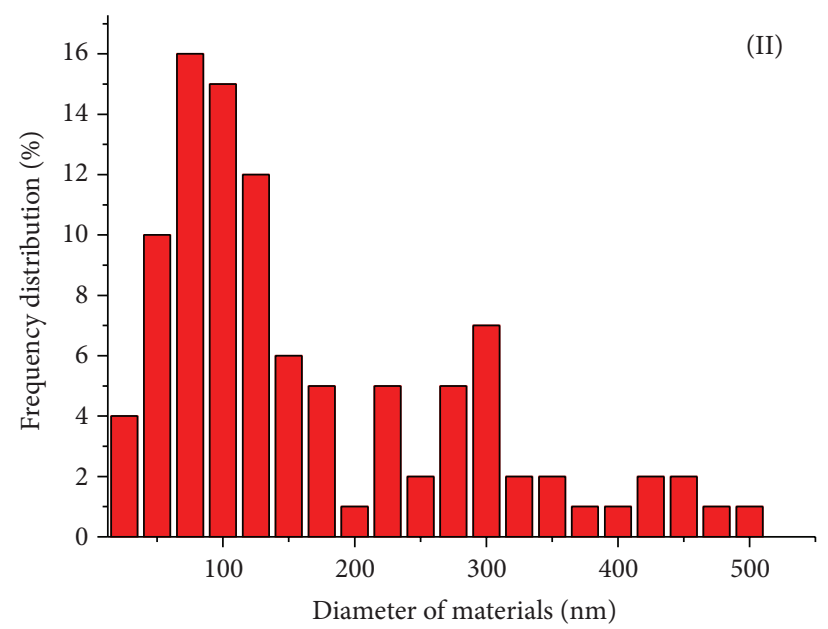

(b)

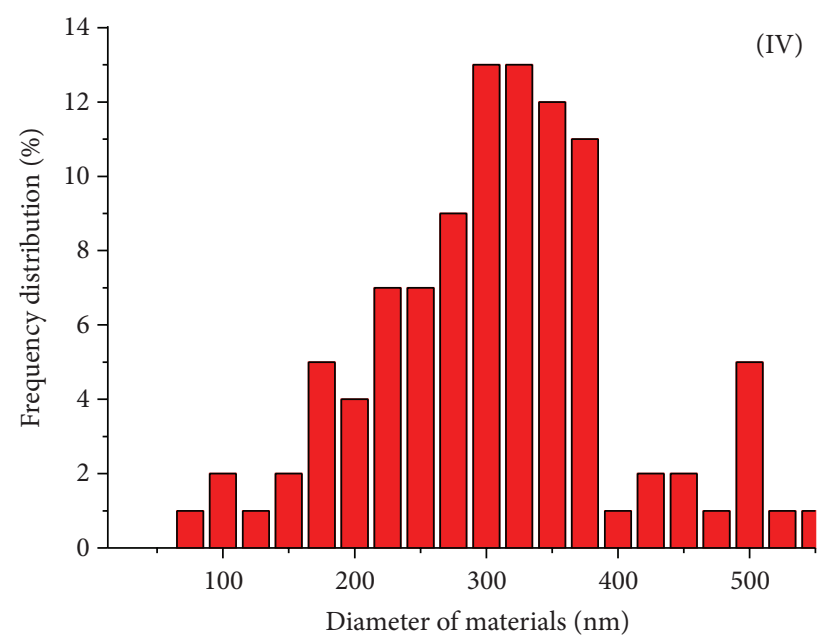

(d)

FIGURE 3: Distributions of electrospun fish collagen during the experiment was (a) $v=0.1 \mathrm{~mL} / \mathrm{h}$ (indicate I); (b) $v=0.5 \mathrm{~mL} / \mathrm{h}$ (II); (c) $v=1.0 \mathrm{~mL} / \mathrm{h}$ (III); (d) $v=1.5 \mathrm{~mL} / \mathrm{h}$ (IV).

grew least in the collagen groups. It means that the different structure fiber scaffolds significantly affect cell growth. At higher flow rate, the fiber stuck together, resulting in porosity decreased. There is too little room to help cell attachment and growth in the scaffold.

Scaffold design [25-33] is to produce an ideal structure that acts as an ECM until host cells can repopulate and resynthesize a new natural matrix. Collagen, as the basic structural element for most connective tissues, plays a prominent role in maintaining the biologic and structural integrity of ECM architecture and presents different morphologies in different tissues which perform different functions. Particulary, fish collagen biomaterials formed instructive extracellular microenvironments for morphogenesis in tissue engineering. Particulary fish collagen is preferred for cell attachment and proliferation, which would be widely useful for tissue regeneration. Further application researches will focus on them.

\section{Conclusions}

In this study, the fish collagen was firstly isolated by flash extraction. The Type I collagen was characterized by FT-IR. It was also found as an appropriate flow rate of solvent for electrospinning. This parameter depended on the diameter and structure of nanofibers scaffold. Further, it significantly affected cell growth.

\section{Conflict of Interests}

The authors declare no possible conflict of interests.

\section{Authors' Contribution}

Gang Zhou and Guimin Zhang equally contributed to this paper. 


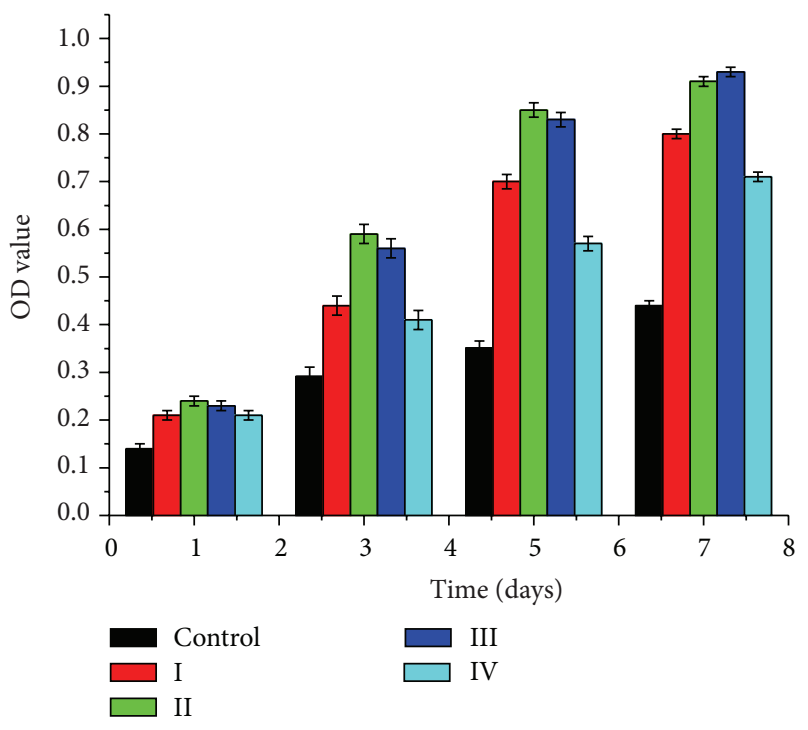

FIGURE 4: MTT assays for proliferation of HEK-293 cells co-cultured with fish collagen at 1, 3, 5, 7 days (Control indicate co-cultured without materials; I indicate $v=0.1 \mathrm{~mL} / \mathrm{h}$; II indicate $v=0.5 \mathrm{~mL} / \mathrm{h}$; III indicate $v=1.0 \mathrm{~mL} / \mathrm{h}$; IV indicate $v=1.5 \mathrm{~mL} / \mathrm{h}$ ).

\section{Acknowledgments}

This study was supported by funds from the National Basic Research Program of China (973 Program, no. 2011CB710901), NSFC Research Grant (11002016, 61227902, 10925208, 11120101001, 81171437, and 81101123), National Key Technology R\&D Program (nos. 2012BAI18B06, 2012BAI 18B05), the 111 Project of China (no. B13003), International Joint Research Center of Aerospace Biotechnology and Medical Engineering, Ministry of Science and Technology of China, and the Fundamental Research Funds for the Central Universities of China.

\section{References}

[1] C. P. Grey, S. T. Newton, G. L. Bowlin, T. W. Haas, and D. G. Simpson, "Gradient fiber electrospinning of layered scaffolds using controlled transitions in fiber diameter," Biomaterials, vol. 34, no. 21, pp. 4993-5006, 2013.

[2] H. Liu, X. Li, G. Zhou, H. Fan, and Y. Fan, "Electrospun sulfated silk fibroin nanofibrous scaffolds for vascular tissue engineering," Biomaterials, vol. 32, no. 15, pp. 3784-3793, 2011.

[3] B. S. Jha, C. E. Ayres, J. R. Bowman et al., "Electrospun collagen: a tissue engineering scaffold with unique functional properties in a wide variety of applications," Journal of Nanomaterials, vol. 2011, Article ID 348268, 15 pages, 2011.

[4] B. S. Jha, R. J. Colello, J. R. Bowman et al., “Two pole air gap electrospinning: fabrication of highly aligned, three-dimensional scaffolds for nerve reconstruction," Acta Biomaterialia, vol. 7, no. 1, pp. 203-215, 2011.

[5] A. Aszódi, K. R. Legate, I. Nakchbandi, and R. Fässler, "What mouse mutants teach us about extracellular matrix function," Annual Review of Cell and Developmental Biology, vol. 22, pp. 591-621, 2006.
[6] C. Pittarate, T. Yoovidhya, W. Srichumpuang, N. Intasanta, and S. Wongsasulak, "Effects of poly(ethylene oxide) and $\mathrm{ZnO}$ nanoparticles on the morphology, tensile and thermal properties of cellulose acetate nanocomposite fibrous film," Polymer Journal, vol. 43, no. 12, pp. 978-986, 2011.

[7] C. C. Roth, "Urologic tissue engineering in pediatrics: from nanostructures to bladders," Pediatric Research, vol. 67, no. 5, pp. 509-513, 2010.

[8] J.-C. Park, T. Ito, K.-O. Kim et al., "Electrospun poly(vinyl alcohol) nanofibers: effects of degree of hydrolysis and enhanced water stability," Polymer Journal, vol. 42, no. 3, pp. 273-276, 2010.

[9] Y. Zhang, J. R. Venugopal, A. El-Turki, S. Ramakrishna, B. $\mathrm{Su}$, and C. T. Lim, "Electrospun biomimetic nanocomposite nanofibers of hydroxyapatite/chitosan for bone tissue engineering," Biomaterials, vol. 29, no. 32, pp. 4314-4322, 2008.

[10] S. Sahoo, L. T. Ang, J. C.-H. Goh, and S.-L. Toh, "Growth factor delivery through electrospun nanofibers in scaffolds for tissue engineering applications," Journal of Biomedical Materials Research Part A, vol. 93, no. 4, pp. 1539-1550, 2010.

[11] L. Cen, W. Liu, L. Cui, W. Zhang, and Y. Cao, "Collagen tissue engineering: development of novel biomaterials and applications," Pediatric Research, vol. 63, no. 5, pp. 492-496, 2008.

[12] M. E. Grant, "From collagen chemistry towards cell therapy-a personal journey," International Journal of Experimental Pathology, vol. 88, no. 4, pp. 203-214, 2007.

[13] G. Veit, B. Kobbe, D. R. Keene, M. Paulsson, M. Koch, and R. Wagener, "Collagen XXVIII, a novel von Willebrand factor A domain-containing protein with many imperfections in the collagenous domain," Journal of Biological Chemistry, vol. 281, no. 6, pp. 3494-3504, 2006.

[14] B. Bakhshandeh, M. Soleimani, N. Ghaemi, and I. Shabani, "Effective combination of aligned nanocomposite nanofibers and human unrestricted somatic stem cells for bone tissue engineering," Acta Pharmacologica Sinica, vol. 32, no. 5, pp. 626-636, 2011.

[15] M. Borjigin, B. Strouse, R. A. Niamat et al., "Proliferation of genetically modified human cells on electrospun nanofiber scaffolds," Molecular Therapy Nucleic Acids, vol. 1, no. 12, p. e59, 2012.

[16] S. C. Kirkland, "Type i collagen inhibits differentiation and promotes a stem cell-like phenotype in human colorectal carcinoma cells," British Journal of Cancer, vol. 101, no. 2, pp. 320-326, 2009.

[17] X. M. Li, Y. Yang, Y. B. Fan, Q. L. Feng, F. Z. Cui, and F. Watari, "Biocomposites reinforced by fibers or tubes, as scaffolds for tissue engineering or regenerative medicine," Journal of Biomedical Materials Research Part A, 2013.

[18] P. Singh, S. Benjakul, S. Maqsood, and H. Kishimura, "Isolation and characterisation of collagen extracted from the skin of striped catfish (Pangasianodon hypophthalmus)," Food Chemistry, vol. 124, no. 1, pp. 97-105, 2011.

[19] F. Pati, B. Adhikari, and S. Dhara, "Isolation and characterization of fish scale collagen of higher thermal stability," Bioresource Technology, vol. 101, no. 10, pp. 3737-3742, 2010.

[20] K. Belbachir, R. Noreen, G. Gouspillou, and C. Petibois, "Collagen types analysis and differentiation by FTIR spectroscopy," Analytical and Bioanalytical Chemistry, vol. 395, no. 3, pp. 829837, 2009.

[21] J. Malašauskiene and R. Milašius, "Mathematical analysis of the diameter distribution of Electrospun nanofibres," Fibres and Textiles in Eastern Europe, vol. 83, no. 6, pp. 45-48, 2010. 
[22] Z. G. Chen, P. W. Wang, B. Wei, X. M. Mo, and F. Z. Cui, "Electrospun collagen-chitosan nanofiber: a biomimetic extracellular matrix for endothelial cell and smooth muscle cell," Acta Biomaterialia, vol. 6, no. 2, pp. 372-382, 2010.

[23] I.-S. Yeo, J.-E. Oh, L. Jeong et al., "Collagen-based biomimetic nanofibrous scaffolds: preparation and characterization of collagen/silk fibroin bicomponent nanofibrous structures," Biomacromolecules, vol. 9, no. 4, pp. 1106-1116, 2008.

[24] C. Ayres, G. L. Bowlin, S. C. Henderson et al., "Modulation of anisotropy in electrospun tissue-engineering scaffolds: analysis of fiber alignment by the fast Fourier transform," Biomaterials, vol. 27, no. 32, pp. 5524-5534, 2006.

[25] X. Li, Q. Feng, X. Liu, W. Dong, and F. Cui, "Collagen-based implants reinforced by chitin fibres in a goat shank bone defect model," Biomaterials, vol. 27, no. 9, pp. 1917-1923, 2006.

[26] X. Li, H. Gao, M. Uo et al., "Effect of carbon nanotubes on cellular functions in vitro," Journal of Biomedical Materials Research Part A, vol. 91, no. 1, pp. 132-139, 2009.

[27] X. Li, H. Liu, X. Niu et al., "The use of carbon nanotubes to induce osteogenic differentiation of human adipose-derived MSCs in vitro and ectopic bone formation in vivo," Biomaterials, vol. 33, no. 19, pp. 4818-4827, 2012.

[28] X. Li, C. A. van Blitterswijk, Q. Feng, F. Cui, and F. Watari, “The effect of calcium phosphate microstructure on bone-related cells in vitro," Biomaterials, vol. 29, no. 23, pp. 3306-3316, 2008.

[29] M. P. Lutolf and J. A. Hubbell, "Synthetic biomaterials as instructive extracellular microenvironments for morphogenesis in tissue engineering," Nature Biotechnology, vol. 23, no. 1, pp. 47-55, 2005.

[30] X. M. Li, L. Wang, Y. B. Fan, Q. L. Feng, F. Z. Cui, and F. Watari, "Nanostructured scaffolds for bone tissue engineering," Journal of Biomedical Materials Research Part A, vol. 101A, no. 8, pp. 2424-2435, 2013.

[31] A. Yin, K. Zhang, M. J. McClure et al., "Electrospinning collagen/chitosan/poly(L-lactic acid-co-e-caprolactone) to form a vascular graft: mechanical and biological characterization," Journal of Biomedical Material Research Part A, vol. 101, no. 5, pp. 1292-1301, 2013.

[32] X. M. Li, Y. Huang, L. S. Zheng et al., "Effect of substrate stiffness on the functions of rat bone marrow and adipose tissue derived mesenchymal stem cells in vitro," Journal of Biomedical Materials Research Part A, 2013.

[33] X. Li, L. Wang, Y. Fan, Q. Feng, and F. Cui, "Biocompatibility and toxicity of nanoparticles and nanotubes," Journal of Nanomaterials, vol. 2012, Article ID 548389, 19 pages, 2012. 

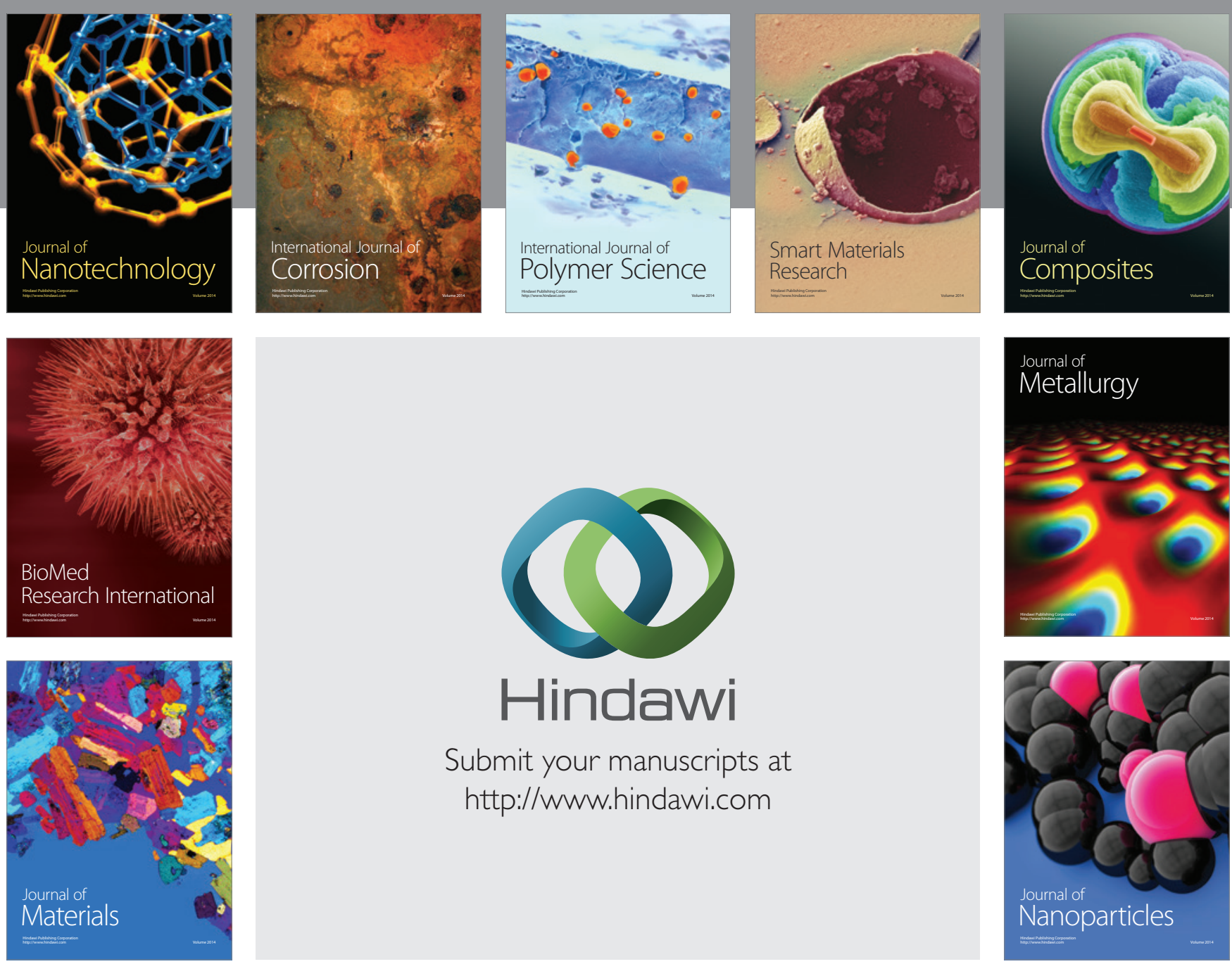

Submit your manuscripts at http://www.hindawi.com
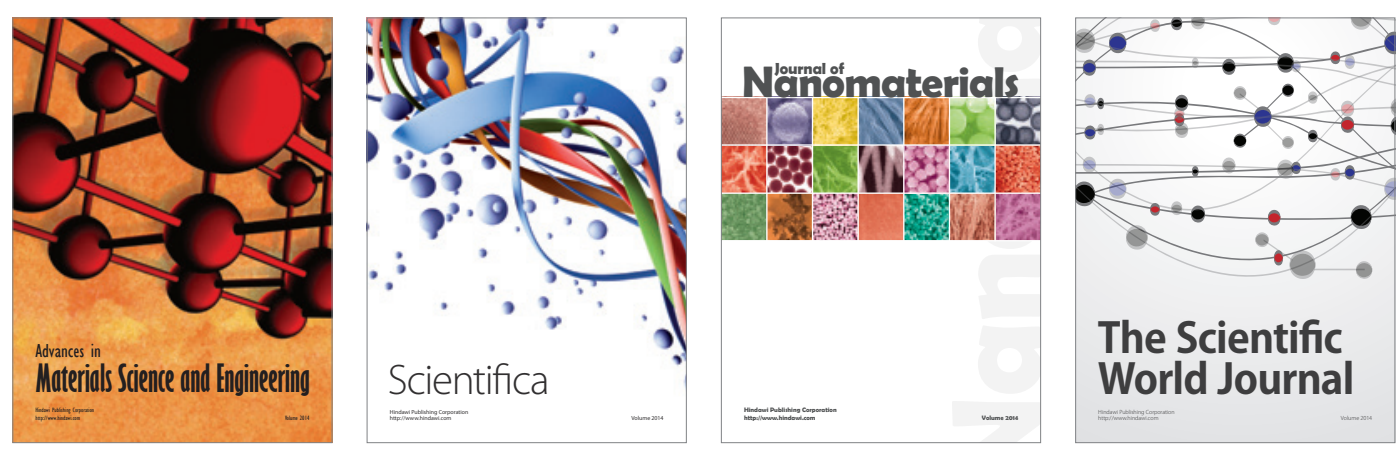

\section{The Scientific World Journal}
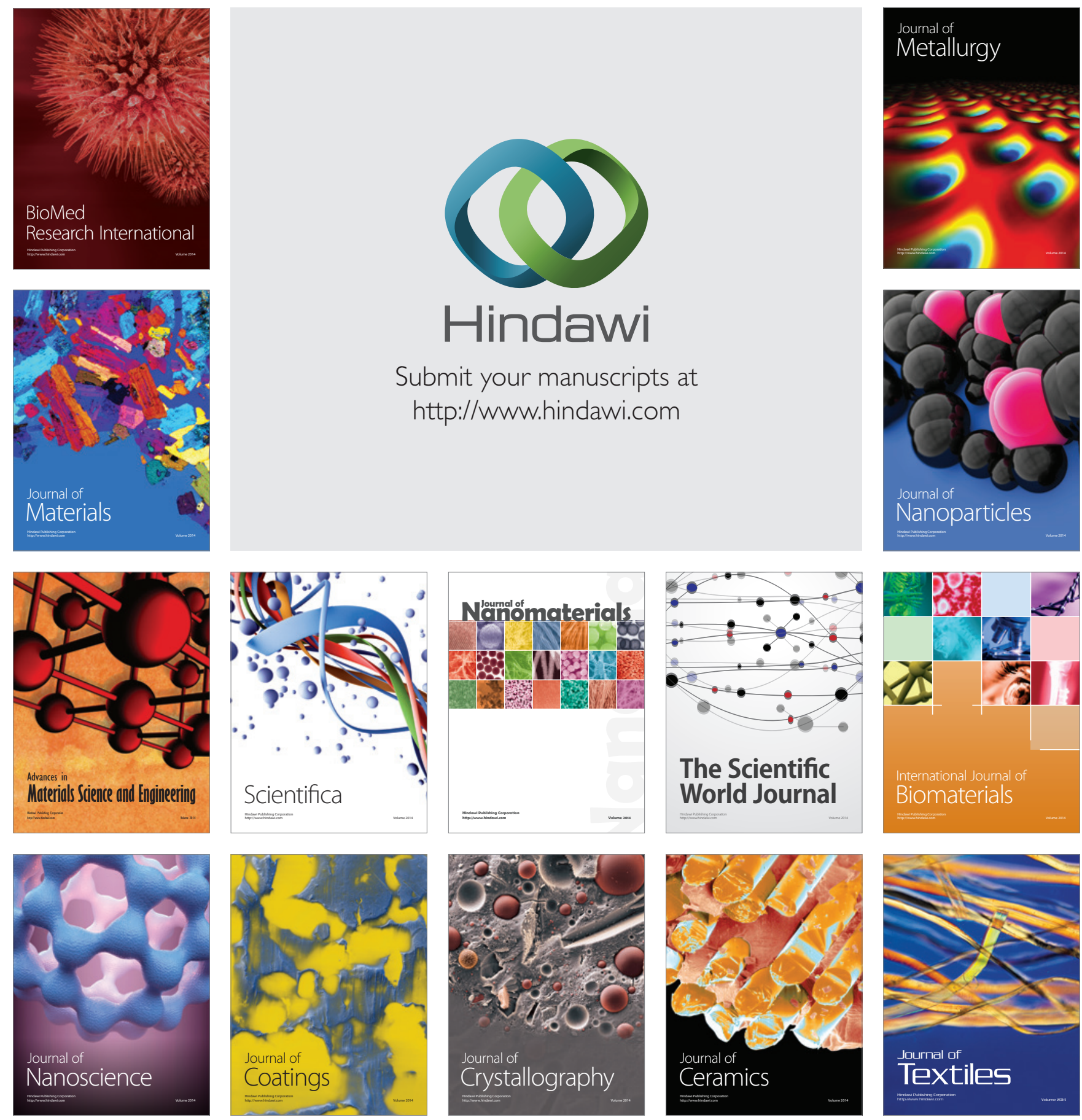